\title{
HEALTH LITERACY PROMOTION AND ITS INSTITUTIONAL ARRANGEMENTS: RETHINKING COLLABORATIVE HEALTH PROMOTION IN THAILAND
}

\author{
Watcharabon Buddharaksa ${ }^{1 *}$, Jonathan S. Davies², and Phudit Tejativaddhana3 \\ 1. Department of Political Science and Public Administration, Naresuan University, Phitsanulok, Thailand \\ 2. Centre for Urban Research on Austerity, De Montfort Univ ersity, Leicester, UK \\ 3. ASEAN Institute for Health Development, Mahidol University, Bangkok, Thailand
}

Correspondence:watcharabonb@nu.ac.th

\begin{abstract}
This research explores institutional arrangements that govern health literacy promotion policies in Thailand since 2014. This study sets the main questions as what are the main institutional arrangements that governed health literacy promotion policies in Thailand since 2014 and can these arrangements be viewed as collaborative health governance? This paper argues that the military coup in 2014 transformed institutional-governing arrangements on health system management and health promotion greatly as many legal-political institutions and various social-political agencies were involved and brought together to promote health and health literacy. A so-called principle of 'collaborative governance' has been employed and implemented to promote health in Thailand recently, however, this study argues that the institutional constraints under authoritarian regime offer a 'fictitious-collaborative health governance' instead. Furthermore, deliberative processes on health literacy promotion regulated by many legal - institutional constraints had characteristics of 'pseudo-deliberation'. This work is qualitative research, and it analyzes and explains researchresults by looking through theoretical concepts of institutionalism and collaborative governance. This study argues that to reach the goal of health literate community and society, Thai health agencies and authorities should re-approach health and health literacy promotion from the bottom-up perspective. Also, overcoming fictitious collaborative health promotion and pseudodeliberation are necessary. To do that, we need a long-term project of building up a 'critical health regime' based on critical education and anti-authoritarianism as major principles.
\end{abstract}

\section{KEYWORDS}

Health Literacy Promotion, Health Promotion, Institutional Arrangements, Collaborative Health Promotion, Thai Public Health 


\section{INTRODUCTION}

Health literacy is defined by WHO as the cognitive and social skills which determine the motivation and ability of individuals to gain access to, understand and use information in ways which promote and maintain good health. [1] Health literacy promotion has been one of the crucial aspects of health promotion in every country. Based on information in the last decade from the Health Information System Office (HISO), Thailand increases in health expenditure were from 147,837 million Baht in 1995 to 248,079 in 2005. [2] Health expenditure costs over the last few years have increased at around 4 percent of GDP as in 2017 but a health literacy promotion policy through multioperations and collaborative works with various social actors could significantly reduce government budget total. [3]

Although the studies on health and health literacy promotions have been fruitful in Thailand, recent studies mainly focus on either development of health literacy measurement tool kits, level of health literacy subjects or roles of any given agencies promoting health education. [4] Existing studies in this tradition explained health literacy while only under the controlled conditions/factors of study. The most crucial weakness of works in this group is the exclusion of significant 'institutional frameworks' such as legal, social, political, and economic structures that could shape behaviour of people or state actions on health literacy promotion in various ways. Lacking in the current knowledge base about health literacy promotion in Thailand is the missing understanding about institutional arrangements that govern health literacy promotion policies in Thailand. Understanding institutional factors is helpful as we could achieve a bigger picture of health literacy promotion in Thailand. Rather than focusing on the implementation of health literacy survey, this study argues that grasping what the institutional constraints in public policy are helps us understand roles and power relations among various actors in health literacy promotion policy subsystems.

This research explores crucial institutional frameworks that govern health literacy promotion policies in Thailand since 2014. Dealing with this issue, this research sets the central questions as what are the main institutional arrangements that govern health literacy promotion policies in Thailand since 2014 and can they be viewed as a collaborative health governance? This paper argues that the military coup in 2014 greatly transformed institutional-governing arrangements about health system management and health promotion. Many legal-political institutions and various social-political agencies are involved and brought together to promote health. A so-called principle of 'collaborative governance' has been employed and implemented to promote health in Thailand recently but nevertheless, this study argues that the institutional constraints under authoritarian regime offer a 'fictitiouscollaborative health governance' instead. Also, deliberative processes about health literacy promotion regulated by many legal-institutional constraints can be characterized as 'pseudo-deliberation'. This work analyzes and explains research results by examining them through the theoretical concepts of institutionalism and collaborative governance which we will describe these in the next section.

\section{METHODOLOGY}

This study focuses on legal and political institutional frameworks that govern public policies which promote health literacy. Therefore, we employ a documentary research method to collect data utilizing primary and secondary sources.[5] Primary sources include the constitution of the kingdom of Thailand, national strategies, and official plans regarding health and health literacy promotions, national health development plan, reports from the Department of Health, Ministry of Public Health, and other related legal entities. In addition, secondary sources include research reports, articles, pamphlets, online articles, and other documents regarding health and health literacy promotions.

Regarding the approaches to analysis, this study uses a theoretically driven content analysis. [6] We will analyze the study results and explain the roles of institutional arrangements that govern health literacy promotion policies in Thailand in the Discussion section by examining them through the concepts of institutionalism and collaborative governance.

\section{INSTITUTIONALISM}

An institutionalist approach offers important insights about factors that shape the behaviour of policy actors. [7] Institutionalism has been the dominant theoretical perspective in social and political sciences since the 1960 s. However, for the areas of public health and health promotion, this institutional approach is relativelynew. 
Although the institutionalist tradition nowadays can be distinguished between new and old institutionalism, this study invites readers to reconsider the old institutionalism as a theoretical framework. [8] Traditional institutionalism can be described as a notion covering the rules, procedures, and formal organisations of government as factors governing people's political behaviour. [9] Social institutions like formal rules, laws, policies, and other formal organisations of government are institutional constraints that help governing policy subsystems. These institutions can be constraining, superimposing conditions of possibility for mobilization, access, and influence. They also limit some forms of action and facilitate others. [10] When considering the interconnection among subsystems of health literacy promotion, this institutionalist approach is helpful as it perceives regulations, rules, laws, and plans of the Thai state as institutional arrangements that direct and steer health literacy promotion. This approach illustrates formal relations of power among social-political actors in the health policy arena within the context of Thai authoritarian regime.

\section{COLLABORATIVE GOVERNANCE}

The term 'governance' has been one of the frequently used vocabulary words in contemporary policystudies and it is defined in various senses. [1 1] The term is often used with a preceding word such as good governance, network governance, global governance, muti-level governance, etc. Governance is a broad term which, at the most general level, usually refers to theories and issues of social coordination and the nature of all patterns of rule. It was also described as a system of rules shaping and regulating the actions of social and political actors; political steering of social relations based on cooperation. In addition, governance also refers to practices of governing. [12] Within various fashions of governance, collaborative governance is gaining popularity as a superior method of policy studies. [13] Broadly collaborative governance could be considered as any method of collective decisionmaking where public agencies and non-state stakeholders engage each other in a consensus-oriented deliberative process. [14]
Ansell and Gash defined a succinct definition of collaborative governance as:

A governing arrangement where one or more public agencies directly engage non-state stakeholders in a collective decision-making process that is formal, consensus-oriented, and deliberative and that aims to make or implement public policy or manage public programs or assets. [15]

This definition involves six crucial characteristics including; 1) the forum which is initiated by public agencies or institutions, (2) participants in the forum include nonstate actors, (3) participants engage directlyin decision making and are not merely"consulted" by public agencies, (4) the forum is formally organized and meets collectively, (5) the forum aims to make decisions by consensus, and (6) the focus of collaboration is on public policy or public management. [16] In addition, collaborative governance is grounded on the principles of trust building, having faceto-face dialogue, shared understanding in a policy community, and commitment to participate from social actors.

This work employs both an institutional approach and collaborative governance to help analyze institutional arrangements that regulate social relationships among policy actors in health literacy promotion.

\section{RESULTS: INSTITUTIONAL ARRANGEMENTS ON HEALTH LITERACY PROMOTION SINCE 2014 MILITARY COUP}

This study sets a major question as what are the main institutional arrangements that govern health literacy promotion policies in Thailand since 2014 ? We found that after the coup health literacy promotion has been one of many important issues that Thai public health authorities aim to pursue and there are many governing institutions that regulate institutional arrangements on health literacy promotion. The results showed in the table below. 
TABLE 1: KEY INSTITUTIONAL ARRANGEMENTS AND GOVERNING INSTITUTIONS ON HEALTH LITERACY PROMOTIONS IN THAILAND SINCE 2014

\begin{tabular}{|c|c|c|}
\hline $\begin{array}{l}\text { Governing } \\
\text { Institutions }\end{array}$ & $\begin{array}{l}\text { Institutional Arrangements on } \\
\text { Health Literacy }\end{array}$ & Regulations/Strategies \\
\hline $\begin{array}{l}\text { National Reform } \\
\text { Council/National } \\
\text { Reform Steering } \\
\text { Assembly }\end{array}$ & $\begin{array}{l}\text { Define health literacy as a } \\
\text { national agenda } \\
\text { Established a national committee } \\
\text { on health literacy and health } \\
\text { communication } \\
\text { Aim to reach health literate } \\
\text { organization and community } \\
\text { Conducts health literacy surveys }\end{array}$ & \\
\hline $\begin{array}{l}\text { Constitution of the } \\
\text { Kingdom of } \\
\text { Thailand, } 2017\end{array}$ & $\begin{array}{l}\text { Chapter V Duties of the State } \\
\text { - Section } 55 \\
\text { Chapter VI Directive principles of } \\
\text { state policies } \\
\text { - Section } 71 \\
\text { Chapter XVI } \\
\text { - Section } 258\end{array}$ & $\begin{array}{l}\text { Section } 55 \text { The State shall ensure that the } \\
\text { people receive efficient public health } \\
\text { services universally, ensure that the } \\
\text { public has the basic knowledge in } \\
\text { relation to health promotion and disease } \\
\text { prevention, and shall promote and } \\
\text { support the advancement of wisdom on } \\
\text { Thai traditional medicine to maximise its } \\
\text { benefits. } \\
\text { Section } 71 \text { The State should strengthen } \\
\text { the family unit which is an important } \\
\text { basic element of society, provide } \\
\text { appropriate accommodation, promote } \\
\text { and develop the enhancement of } \\
\text { health in order to enable people to } \\
\text { have good health and strong mind, as } \\
\text { well as promote and develop } \\
\text { excellence in sports and to maximise the } \\
\text { benefit for the people. } \\
\text { Section } 258 \text { National reform in various } \\
\text { areas shall be carried out to at least } \\
\text { achieve the following results: } \\
\text { g. Other Areas: } \\
\text { (4) adjusting the health security system in } \\
\text { order that the people are granted } \\
\text { comparable rights and benefits from the } \\
\text { management thereof and from access } \\
\text { to quality and convenient service. } \\
\text { (5) establishing a primary health care } \\
\text { system in which there are family } \\
\text { physicians to care for the people in an } \\
\text { appropriate proportion. }\end{array}$ \\
\hline
\end{tabular}




\begin{tabular}{|c|c|c|}
\hline $\begin{array}{l}12^{\text {th }} \text { National Health } \\
\text { Development Plan } \\
(2017-2021)\end{array}$ & $\begin{array}{l}\text { Strategy } 1 \text { Actively empowered } \\
\text { human well-being for Thais } \\
\text { - } 4 \text { Goals } \\
\text { - } 4 \text { Measures }\end{array}$ & $\begin{array}{l}\text { Goal } 1 \text { Thai people at all ages are } \\
\text { healthy and strong } \\
\text { Goal } 2 \text { Public policy engage with health } \\
\text { promotion and reducing risks on health } \\
\text { Goal } 3 \text { Public communication regarding } \\
\text { on risks reducing for health behaviour } \\
\text { changing } \\
\text { Goal } 4 \text { Integration among institutions } \\
\text { and health agencies for health } \\
\text { promotion, disease prevention, and } \\
\text { customer protection on health services } \\
\text { Measure } 1 \text { Building networks and } \\
\text { alliances between social groups, local } \\
\text { authorities, NGOs, civil society } \\
\text { organisations, } \\
\text { Measure } 2 \text { Develop "Health in All Policy" } \\
\text { Measure } 3 \text { Promote "Health Literacy" } \\
\text { Measure } 4 \text { Improve systems that } \\
\text { determinate health }\end{array}$ \\
\hline $\begin{array}{l}\text { National Strategy } \\
(2018-2037)\end{array}$ & $\begin{array}{l}\text { Aspects related to Public Health in } \\
\text { Strategy } 3 \text { Development of Human } \\
\text { Capital } \\
\text { - Issue } 4.5 \text { Enhancing Well- } \\
\text { Being among Thai people }\end{array}$ & $\begin{array}{l}\text { Issue 4.5 Enhancing Well-Being among } \\
\text { Thai people } \\
\text { 4.5.1 Promote Health Literacy by } \\
\text { developing knowledge and health } \\
\text { communication. Support all sectors to } \\
\text { participate in health literacy promotion. }\end{array}$ \\
\hline $\begin{array}{l}\text { Office of } \\
\text { Department of } \\
\text { Health (DoH) } 4.0 \\
\text { and Health Literacy, } \\
\text { Ministry of Public } \\
\text { Health }\end{array}$ & $\begin{array}{l}\text { - } \begin{array}{l}\text { Promotion and Prevention } \\
\text { - }\end{array} \text { Health literate organization } \\
\text { (Government, Civil Society, } \\
\text { Private) } \\
\text { - } 66 \text { Key Messages for HL }\end{array}$ & $\begin{array}{l}\text { 1. Survey national health literacylevels } \\
\text { 2. Develop required knowledge on } \\
\text { health literacy } \\
\text { 3. Enhance human development } \\
\text { 4. Develop health communication } \\
\text { system } \\
\text { 5. Support research and innovation } \\
\text { 6. Support and engage in development } \\
\text { of health literate organization, school, } \\
\text { and community }\end{array}$ \\
\hline $\begin{array}{l}\text { Health Education } \\
\text { Division, } \\
\text { Department of } \\
\text { Health Service } \\
\text { Support, Ministry of } \\
\text { Public Health }\end{array}$ & $\begin{array}{l}\text { - Health literacy evaluation } \\
\text { program and survey }\end{array}$ & \\
\hline
\end{tabular}




\begin{tabular}{|l|l|l|}
\hline $\begin{array}{l}\text { Thai Health Literacy } \\
\text { Association (THLA) }\end{array}$ & $\begin{array}{l}\text { - Cooperation with health } \\
\text { agencies on health } \\
\text { communication and key } \\
\text { messages on health literacy } \\
\text { - Provide policy recommendations } \\
\text { on health literacy to the public }\end{array}$ & \\
\hline $\begin{array}{l}\text { Regulations of the } \\
\text { Office of the Prime } \\
\text { Minister on District } \\
\text { Health System }\end{array}$ & $\begin{array}{l}\text { - Establishment of the District } \\
\text { Health Board (DHB) }\end{array}$ & $\begin{array}{l}\text { Duties and responsibilities of the DHB } \\
\text { 1. Set goas for quality of lives } \\
\text { improvementin a district } \\
\text { 2. Integration among state agencies in a } \\
\text { district }\end{array}$ \\
& $\begin{array}{l}\text { 3. Support collaboration between all } \\
\text { sectors } \\
\text { 4. Provide recommendation and being a } \\
\text { consultant on quality of lives } \\
\text { improvement in a district } \\
\text { 5. Evaluate all works regarding quality of } \\
\text { lives in a district }\end{array}$ \\
\hline
\end{tabular}

\section{DISCUSSION}

This work set as a minor question for this study to examine if the institutional arrangements that govern health literacy policies in Thailand after the Coup of 2014 are true collaborative health governance. The authors argue that institutional arrangements that govern health literacy policies since 2014 are only collaborative governance in their appearance and actually are fictitious and deliberative processes written in various regulations which is pseudo-deliberation.

\section{FICTITIOUS COLLABORATIVE GOVERNANCE}

Thai state has been struggling in political crises in the last two decades. The country faced two military coups in 2006 and 2014. The coups brought several structural changes central to the two constitutions in 2007 and 2017. [17] Public health and health promotions since 2014 therefore had significant consequences. As the results of the study illustrated the Thai authorities attempt to bring collaboration and collaborative governance among government agencies and civil society actors. However, the authors argue that under such political and social regimes like in contemporary Thailand, the Thai authorities only offer a 'fictitious-collaborative health governance' because true collaborative governance is based on trust building, face-to-face dialogue, shared understanding in a policy community, and commitment to participate from social actors.

What is interesting and should be discussed here is that basically the institutional constraints on health literacy promotion have been ordered in a top-down manner. Collaborative governance regarding health governance in Thailand was not driven by the creation of coordinating institutions like NGOs or other civil society institutions [18] Rather, collaborations in health literacy policies were established upon 'coercion' from various governmental, bureaucratic, and official boards set up since 2014 via many legal forms. Collaboration in this sense is, what we argued as fictitious. Indeed, it is a collaboration between several state actors under laws and orders rather than active participation from non-state actors like private and civil societysocial groups.

\section{PSEUDO-DELIBERATION}

Another important issue is about deliberation. Thai public health authorities have been regulated by various institutional arrangements that promote deliberative processes as guidelines for health literacy promotion. Deliberative policy formation and implementation require deliberative engagement among social actors at the 
centre. [19] Deliberative decision-making is also a crucial aspect of deliberative public policy process. Nevertheless, we argue that in the case of Thailand, public policy processes are overwhelmed by the bureaucratic regime which basically is closely tied to the authoritarian regime. The coup in 2014 successfully regained resources and strengths for Thai bureaucratism. This bureaucratic-led regime offers, we argued, a pseudo-deliberative policy process. We contend that deliberative democracy and deliberative public policy could emerge within social conditions that underpin the practices of collaboration. [20] Nonetheless, the Thai state in the context of the post2014 military coup and the ongoing military-led government afterward did not engage or create collective norms into society. Deliberations through authoritarian institutional arrangements created barriers to citizen engagement and democratic participation. [21] Therefore, it could be seen that health literacy promotion in Thailand since 2014 has been operating on what we called a 'pseudo-deliberation' basis.

\section{RETHINKING COLLABORATIVE HEALTH PROMOTION}

This study suggests that health agencies and authorities of the Thai state should rethink and reconsider their approach to promote health literacy. Firstly, health and health literacy promotions cannot be achieved through the top-down approach. It seems normal for Thai authorities to centralize planning and regulating from central authorities in Bangkok and deliver policy to implement in the district and local areas. Based on the results showed earlier, governing agencies regulate health literacy promotion on the onesize-fits-all basis. Instead, the approach the Thai health agencies should employ is the bottom-up health literacy promotion. Rather than ordering several state and nonstate actors to act on promoting health literacy, it should initiate the participation of local communities under guidance from official health agencies. Secondly, health agencies should not over focus on health literacysurvey. It is only a tool to help planning for long-term health literacy promotion. Thirdly, the fictitious collaboration should be overcome. Health literacy promotion is not a task to be conducted alone. It requires active engagement from all sectors; official health agencies, civil society organizations, business, local authorities, local communities, and households. Building a strong and sustainable network of collaboration demands political decentralization as a prerequisite. Collaborative health promotion, therefore, should have deliberative democracy as a precondition. Lastly, in the long-term, Thai health authorities should create a sustainable 'critical health regime'. A new regime requires transforming existing patterns of social relations in terms of political, economic, and social aspects in each local community. In addition, a 'critical' understanding of health literacy and health related knowledge can be achieved only by providing 'critical' education with antiauthoritarianism as a point of departure. It could be concluded that all these factors are all interconnected, and it requires time to develop such a sustainable health regime.

\section{CONCLUSIONS}

Thai health authorities should rethink their health and health literacy policies promotion. Within such an authoritarian regime, institutional arrangements that govern health literacy promotion subsystems deliver health literacy policies in a top-down manner. Although these institutional constraints indicate policy actors to work deliberatively and collaboratively, this study argues that it is a fictitious collaboration and a pseudo-deliberation. Legal institutions, rules, and regulations regarding health promotions created under the junta government in post-2014 are only collaborative in their form but highly centralized and authoritative in their real content. The authors argued that to reach the goal of a health literate community and society, we should re-approach health and health literacy promotion from the bottom-up perspective. Also overcoming fictitious collaborative health promotion and pseudo-deliberation are necessary. To do that, we need a long-term project of building up a 'critical health regime' based on critical education and anti-authoritarianism as major principles.

\section{References}

1. World Health Organization. Health Literacy. Available: https://www.who.int/healthpromotion/healthliteracy/en/ (Accessed 1 June 2021)

2. Recent study confirmed that health expenditure in Thailand increased greatly since 2015. See for example, Karim MR. Distributional effects of public healthcare and education expenditure: A case of Thailand. Jurnalul Practicilor Comunitare Pozitive 2021; $21(2): 15-30$.

3. Haun JN, Patel NR, French DD, Campbell RR, Bradham DD, Lapcevic WA. Association between health literacy and medical care costs in an integrated healthcare system: a regional population based 
study. BMC health services research. 2015 Dec; 15(1):1-1.

4. For example; Pobhirun T, PinitsoontornS. The association between health literacy and pesticide use behaviors among sweet corn farmers in the Pak Chong district of Thailand: a cross-sectional study. F1000Res 2019; 8: 448.; Nilnate W, Hengpraprom S, Hanvoravongchai $P$. Level of health literacy in Thai elders. J of Health Res 2016;30(5): 315-21.

5. GorskyM, Mold A. Documentary analysis. In Pope C and Mays N. Qualitative research in health care. Oxford: Wiley Blackwell; 2020.

6. Stemler SE. Content analysis. In Kosslyn SM and Scott RA. Emerging trends in the social and behavioral sciences: An Interdisciplinary, Searchable, and Linkable Resource. Hoboken: John Wiley\&Sons; 2015.

7. Lowndes $\vee$. The institutional approach. In Lowndes $V$, Marsh D and Stoker $G$. Theory and methods in political science. Basingstoke: Palgrave Macmillan; 2017.

8. Ibid.

9. Amenta E, Ramsey KM. Institutional theory. In Leicht KT and Jenkins JC. Handbook of politics. New York: Springer; 2010.

10. Peters BG. Institutionalism and public policy. In Peters $B G$ and Zittoun P. Contemporary approaches to public policy. London: Palgrave Macmillan; 2016.; See also Immergut EM. Institutional constraints on policy. In Moran M, Rein M, and Goodin R. The Oxford handbook of public policy. Oxford: Oxford University Press; 2006.

11. BevirM. Governance as theory, practice, and dilemma. In Bevir M. The SAGE handbook of governance. London: Sage; 2011.

12. Gash A. Collaborative governance. In Ansell $C$ and Torfing J. Handbook on Theories of Governance. Cheltenham: Edward Elgar Publishing; 2016.

13. Ibid.

14. Ansell C, Gash A. Collaborative governance in theory and practice. J of pub ad research and theory 2008; 18(4): 543-71.

15. Ibid.

16. Ibid.

17. Tonsakulrungruang K. Constitutional Amendment in Thailand: Amending in the Spectre of Parliamentary Dictatorship. J of Comparative Law 2019; 14(1):173-8.
18. Griggs S, Howarth D, Feandeiro A. The logics and limits of "collaborative governance" in Nantes: Myth, ideology, and the politics of new urban regimes. J of Urban Affairs 2020;42(1): 91-108.

19. On deliberative public policy see for example Peters BG. Reframing Public Policy: Discursive Politics and Deliberative Practices. Political science quarterly 2004; 119(3): 566-8. And Bächtiger A, Dryzek JS, Mansbridge $\mathrm{J}$, Warren ME, editors. The Oxford handbook of deliberative democracy. Oxford: Oxford University Press; 2018.

20. Griggs S, Howarth D, Feandeiro A. The logics and limits of "collaborative governance" in Nantes: Myth, ideology, and the politics of new urban regimes. J of Urban Affairs 2020;42(1): 91-108.

21. Ibid 